\title{
Web-Based Instructional Media Development Using Powtoon for Quantity Surveying Subject
}

\author{
NM Sari ${ }^{1}$, Ari Syaiful R ${ }^{2}$, Muvi Yandra ${ }^{3}$ \\ Universitas Negeri Padang, Padang, Indonesia \\ \{nadrasari@ft.unp.ac.id ${ }^{1}$ \}
}

\begin{abstract}
This study aims to help students' learning process whose major civil engineering in comprehending Quantity Surveying subject by providing an innovative web-based instructional media using Powtoon. The subject is chosen since it requires advanced level for comprehension and mastering the material. This research is a Research and Development (R \& D) using 4D development model (define, design, develop and disseminate). Data collection techniques include field notes, expert validation, questionnaires, and practicality test. The instructional media is said to be valid based on the result of expert validation judgment. The small group response result for their learning achievement is in a Very Good category, while the media practicality is in a Very Good category and highly positive. These results prove that Powtoon as an instructional media is very good to be used in the learning process.
\end{abstract}

Keywords: Development Media Animation, Powtoon, Quantity Surveying

\section{Introduction}

Quantity Surveying is a compulsory subject for students majoring Civil Engineering in Universitas Negeri Padang (UNP). The instructional objectives of this subject are to calculate the complete Cost Budget Plan in a construction plan, network and activities arrangement, workforce and equipment planning, and other supporting resources [1]. These objectives make the subject becomes one of the subjects that requires an advanced level of understanding and comprehension to reach its output goals. Thus, the output of the course can be achieved.

An initial observation was conducted in Civil Engineering Department, Universitas Negeri Padang to find out the needs of an innovative instructional media development for the subject. Some points were noted; (1) This subject is a difficult subject for the students since they need to count the cost budget plan for volume measurement of each construction detail item, number of workers needed, duration of the project, and the cost of a building starting from the beginning until finishing. (2) the students' difficulty in understanding the material causes a lack of mastery in the course, (3) the instructional media existed is not effective in supporting students' understanding, (4) the students' difficulty in getting good grades. Furthermore, it is necessary to develop an instructional media to solve these problems and to support a learning process. This media plays an important role in facilitating the process of delivering the knowledge effectively [2]. In the learning process, the media has a function as an intermediary 
used by humans to convey information and deliver ideas or opinions to recipients [3]. The use of instructional media in the teaching and learning process arouses desire and motivation to learn and increases understanding for particular subjects [4].

Today 4.0 industrial revolution makes Information and Communication Technology (ICT) to be a significant element in the educational sector. To integrated ICT in the teaching and learning process, some web-based applications become more popular and appropriate to be used. It is assumed that these applications can increase students' willingness and motivation in learning. It can also eliminate the students' boredom in learning. The web-based applications can be in the form of software or SaaS-based animation videos (Software as a Service) that can be accessed online $[5,6]$.

Further, an up to date and a very popular Web Tool which can create animated videos is Powtoon (www.powton.com). This application provides users to create animated presentations by providing objects, images, music, and sound [6,7]. It uses Adobe Flex technology that produces XML files that were established in January 2012. Then, the beta version was released in August of the same year [8]. Powtoon operations are similar to PowerPoint, Impress, or even Prezi which uses slides by adding text and images. It also allows the animation to be merged with the sounds or music which are available in the same application or added from other sources. The result of this combination is a product that combines PowerPoint presentations with animation. There are some of the common advantages offered by this product; (1) allows individuals to display or present any interesting topics and shares them with others, (2) attracts audiences' attention if the presentation is well designed. (3) requires the students to read and synthesize information to be presented, (4) is easy to understand, (5) improves the ability to integrate visual, auditory, and motion resources, (6) is affordable prices, (7) is easy to use/compatible with several other systems $[8,9]$.

Powtoon can produce more interesting and modern instructional media because this media can be made with various cartoon animation effects. It provides an efficient, effective, and enjoyable method in delivering the material with shorter time duration [4-6]. The role of developing Powtoon as an instructional media leads the students' understanding of the lesson to be better and motivates the students to learn. The two indicators create a learning atmosphere that attracts attention to improving learning interest and outcomes. Thus, it is a need to develop such instructional media to make teaching and learning process more advantageous.

\section{Research Method}

The type of this study was a Research and Development (R\&D) study that included a 4D model with several stages such as defining, designing, developing, and disseminating.

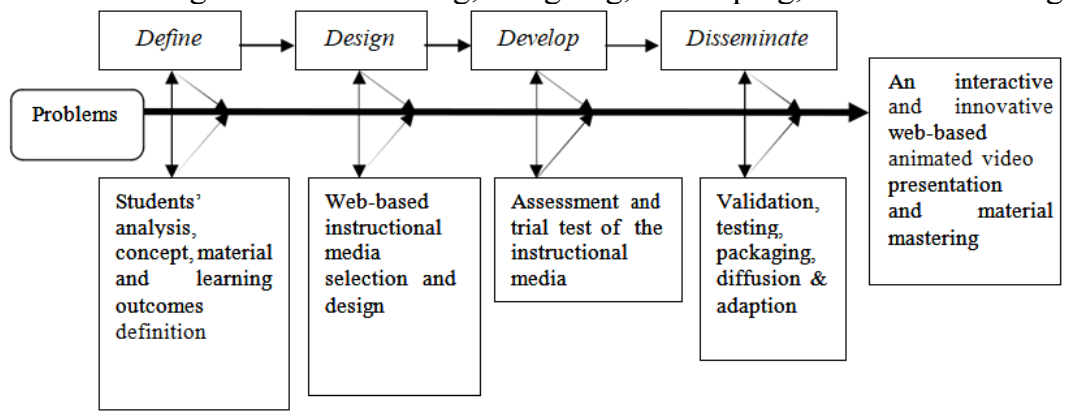


Fig. 1. The scheme of instructional media development using 4D model $[9,10]$

There were some benefits of the 4-D model. It provided detail procedures or steps in the development stages. It was also more appropriate to be used as a basis for developing learning tools because the descriptions were more complete and systematic. It involved experts in development to accommodate judgment, advice, and input of the revision before the field trial conducted [11].

\subsection{Research Instruments}

The instruments in this study were in the form of questionnaires distributed to samples that had been chosen civil engineering student FT UNP in small class.

\subsection{Data Analysis Technique}

A brief description of the technical analysis of the data used in this study was as follows.

\section{The Data Validation of the Instructional Media}

The data validation analysis of the media was done to find out whether the developed media met the validators' criteria or not. This validation used expert validation sheet. In this case, the validators were a media expert and lecturers who teach the subject. The score was categorized as a validator score $[12,13]$.

Table 1. Validators' Assessment Score Interval

\begin{tabular}{cc}
\hline Score interval & Category \\
\hline$X>4,21$ & Very Good \\
$3,40<X \leq 4,21$ & Good \\
$2,60<X \leq 3,40$ & Enough \\
$1,79<X \leq 2,60$ & Less \\
$X \leq 1,79$ & Very Less \\
\hline
\end{tabular}

Note: RTV is the total average of validators' assessment result

\section{Respondents' Data Analysis}

This analysis aimed to find out how the students response the development of instructional media using Powtoon. The category of assessment results for individual tests and small group tests can be seen in table 3 .

\begin{tabular}{cc}
\multicolumn{2}{c}{ Table 2. Respondents' Assessment } \\
\hline Score Interval & Category \\
\hline $75 \% \leq \mathrm{NR} \leq 100 \%$ & Highly Positive \\
$50 \% \leq \mathrm{NR} \leq 75 \%$ & Positive \\
$25 \% \leq \mathrm{NR} \leq 50 \%$ & Less Positive \\
$0 \% \leq \mathrm{NR} \leq 25 \%$ & Negative \\
\hline \multicolumn{2}{r}{ Source: $[14]$}
\end{tabular}

The results the individual tests, small group tests, and the students' responses were converted using the guidelines below: 
Table 3. Achievement Percentage

\begin{tabular}{ccc}
\hline Achievement Percentage & Category & Description \\
\hline $90 \%-100 \%$ & Very good & No revision \\
$75 \%-89 \%$ & Good & Few revisions \\
$65 \%-74 \%$ & Sufficient & Some revisions \\
$55 \%-64 \%$ & Less & Many revisions \\
$0-54 \%$ & Fail & Revise all \\
\hline & Source: $[14]$ &
\end{tabular}

\section{Result and Discussion}

\subsection{Defining stage}

The first thing to do in defining stage was a needs analysis. This analysis aimed to determine the needs, advantages, and disadvantages of existed instructional media in the learning process, especially in the Quantity Surveying subject. An observation was conducted in even semester (January-June) 2019 by gathering information from various sources such as interviews, books, journals, expert opinions, and others. There were some results from the observation. First, the media used in the learning process by the lecturers was only Powerpoint. Meanwhile, it was believed that Powerpoint was less applicable for the learning process. Second, the lack of availability of interactive multimedia-based instructional media. Finally, an interactive multimedia-based instructional media helps to improve learning outcomes and stimulate the students' learning motivation. Moreover, the curriculum used in the development of this study was 2013 curriculum which aimed to prepare Indonesian people to have life skills as individuals and citizens who are faithful, productive, creative, innovative, and effective and able to contribute to the life of the community, nation, state, and world civilization [15].

The next stage was conducting students' analysis who took Quantity Surveying subject. Considering the concept, material formulation, and learning goals were very necessary for doing this stage to achieve the goals. The material to be developed should be aligned with the syllabus. The materials that were aligned to the syllabus were basic materials, for example, the calculation of the structure volume and the budget plan for small-scale building structures. The selection of these materials considered the number of students who did not understand how to calculate the things. Thus, it made them difficult to understand the next material. The result of this analysis found that Web-based instructional media development (Powtoon) was able to: (1) increase enthusiasm in the learning process because the material was presented in the form of creative and unique animations. Its display was easy to be understood, (2) the learning objectives were achieved, (3) the learning outcomes were improved.

\subsection{Designing Stage}

There were some stages in designing the instruction media:

\section{a) Media Design}

The designing of the instructional model using the Web-based animated video creation such as Powtoon was basically a tool or media in the learning process. The material in making 
this media must be aligned with the learning material. Thus, the media can be used in the learning process. However, there were some specifications of a laptop or PC that can be used for this application. The laptop should use Quad Core Celeron processor or above. The RAM was at least 1GB. It should have VGA (On Board), and it must have a stable internet connection.

\section{b) Editing Process}

There were two additional software used to edit the animated video:

1. Pinnacle Studio, this tool was functioned to do video editing, such as cutting the film, smoothing the video to make it nice, and recording video.

2. Audacity, this tool was functioned to record and provide sound effects, such as adding, reducing, and correcting sound files. Besides, users can also create with their own voice.

\section{c) Finishing Process}

The last thing to do in designing stage was applying the media to all multimedia or gadget programs. Before it was applied, the file format had been changed using the format factory.

\subsection{Developing Stage and Dissiminate}

The developing stage was a testing stage of the developed instructional media. It aimed to find out whether the media was good and can be applied or not. To find out this result, a validity test was conducted on the experts and construct validity. The error would be corrected based on the results of the validators' judgment. In this stage, two criteria measured were validity and practicality. Referring to the validity result, the validity test was done twice:

Table 4. The Experts' Validity Result

\begin{tabular}{|c|c|c|c|c|}
\hline Aspect & Score P1 & Score P2 & Category & Final Description \\
\hline Media & 3,6 & 4,6 & Very Good & No revisions \\
\hline Content & 3,5 & 4,4 & Very Good & No revisions \\
\hline Language & 3,0 & 4,0 & Good & Few revisions \\
\hline
\end{tabular}

The table above showed that the developed instructional media was in the category of valid with few revisions. After that, it needed to take into account the respondents' assessment. Further, the media was applied to the students in the small group at the class to be scored in the aspect of its media, content, and language. This assessment was conducted by assigning the questionnaire to the students. The result of the respondents' assessment can be seen in table 5, while the practicality test result can be seen in table 6 .

Table 5. The Respondents' Assessment (Small Group)

\begin{tabular}{|c|c|c|c|}
\hline Aspect & Assessment Score & Category & Category \\
\hline Media & 94 & Highly Positive & Very Good \\
\hline Content & 92 & Highly Positive & Very Good \\
\hline Language & 86 & Highly Positive & Good \\
\hline \multicolumn{4}{|c|}{ Table 6. Practicality Test Result } \\
\hline Users & Assessment Criteria & Average Score & Category \\
\hline Lecturer & $\begin{array}{ll}\text { a. } & \text { Easiness } \\
\end{array}$ & 4,4 & Very Good \\
\hline
\end{tabular}




\begin{tabular}{llll}
\hline Users & Assessment Criteria & Average Score & Category \\
\hline \multirow{4}{*}{ Students } & b. Benefit & & \\
& c. Display & & \\
& d. Time & 4,6 & Very Good \\
& a. Easiness & & \\
& b. Benefit & & \\
& c. Display & & \\
& d. Time & & \\
\hline
\end{tabular}

The media practicality was assessed based on the criteria to be achieved. This assessment was given by the lecturers and students. The results of the assessment said that the media was very good for its practicality with an average score of 3.56 from both users. Table 4 and 6 could be meant that the development of instructional media using Powtoon got a very positive response. This finding can be claimed since the validity level of the media was highly valid with few revisions and the respondents' assessment percentage was highly positive with good category. In conclusion, valid instructional media can be applied to the learning process. The disseminating stage then was deployed using CD storage, flash disk, or smartphone. The students later can study the material anytime and anywhere.

\section{Conclusion}

The development of web-based instructional media such as Powtoon is done by using the R\&D method that includes 4D stages which start from doing some analysis such as curriculum, material, media, and students. The next step is to compile teaching materials and design the initial media (making flowcharts, storyboards, and media-making processes). The third step is to test the validity and practicality. Then, the developed instructional media in this study is in a very valid category, very positive acceptance from the respondents, and a very good category for its practicality. Finally, it proves that the development of Powtoon media is very good to be used in the learning process.

\section{References}

[1] Panduan Akademik UNP Tahun Ajaran 2017/2018.

[2] Juliana, Erviyenni, and Rini, "the Development of Learning Media Based Powtoon in Atomic Structure Subject in First Grade Powtoon Pada Pokok Bahasan Struktur Atom," pp. 1-10.

[3] mayra A. Villar, Developing A Mobile Learning Startegi, vol. 2013. Amerika: ASTD.

[4] Y. Andrianti, R. Susanti, and Hudaidah, "Pengembangan Media Powtoon Berbasis Audiovisual pada Pembelajaran Sejarah,” J. Criksetra, vol. 5, no. 9, pp. 58-68, 2016.

[5] S. Fajar, C. Riyana, and N. Hanoum, "Pengaruh Penggunaan Media Powtoon Terhadap Hasil Belajar Siswa Pada Mata Pelajaran Ilmu Pengetahuan Sosial Terpadu," J. Pengajaran MIPA, vol. 3, no. 2, pp. 101-114, 2017.

[6] N. H. Jatiningtias, "Kurikulum dan teknologi pendidikan fakultas ilmu pendidikan universitas negeri semarang 2017," Pengemb. Media Pembelajaran Powtoon Untuk Meningkat. Has. Belajar Siswa Mata Pelajaran IPS Mater. Penyimpangan Sos. Di SMP Negeri 15 Semarang, p. 76, 2017. 
[7] S. Fajar, C. Riyana, and N. Hanoum, "Pengaruh Penggunaan Media Powtoon Terhadap Hasil Belajar Siswa pada Mata pelajaran Ilmu Pengetahuan Sosial Terpadu," Edutcehnologia, vol. 30, no. 4. Bandung, p. 369, 2017.

[8] M. H. R. Pais, F. P. Nogués, and B. R. Muñoz, "Incorporating powtoon as a learning activity into a course on technological innovations as didactic resources for pedagogy programs,” Int. J. Emerg. Technol. Learn., vol. 12, no. 6, pp. 120-131, 2017.

[9] Media Penddidikan: Pengertian, Pengembangan, dan Pemanfaatannya. Jakarta: RajaGrafindo Persada, 2010.

[10] Metode Penelitan Pendidikan Pendekatan Kualitatif, Kuantitatif, dan R\&D. Bandung: Alfabeta.

[11] Y. Miaz, Y. Helsa, Desyandri, and R. Febrianto, "Cartography in designing digital map using Adobe Flash CS6," J. Phys. Conf. Ser., vol. 1088, 2018.

[12] Y. D. Puspitarini, M. Akhyar, and D. Djono, "Developing Powtoon-Based Video Learning Media for Five Grade Students of Elementary School,” vol. 165, no. Iccsr, pp. 173-177, 2018.

[13] Y. D. Puspitarini, M. Akhyar, and . D., "Development of Video Media Based on Powtoon in Social Sciences,” Int. J. Educ. Res. Rev., pp. 198-205, 2019.

[14] I. D. Saadah, "Pengembangan Media Pembelajaran Matematika Berbasis Video Animasi Dengan Menggunakan Adobe After Effect," pp. 1-71, 2018.

[15] Gerlach and Eli, No TitleTeaching \& Media: A Systematic Approach, Second Edi. Boston: Pearson Education, 1971. 